RESEARCH NOTE

\title{
Tetrazolium test for assessment of seed viability of atemoya (Annona cherimola Mill. x A. squamosa L.) ${ }^{1}$
}

\author{
Juliana Iassia Gimenez ${ }^{2 *}$, Gisela Ferreira ${ }^{3}$, Claudio Cavariani ${ }^{4}$
}

\begin{abstract}
The study aimed to adapt the tetrazolium test to assess the viability of atemoya (Annona cherimola Mill. x A. squamosa L.) seeds. The experimental design was completely randomized in $3 \times 3$ factorial arrangement (tetrazolium salt concentrations $\mathrm{x}$ exposure times), totaling 9 treatments with four replicates of 25 seeds. After immersion in water for 24 hours, the seeds were longitudinally sectioned and exposed to three tetrazolium salt concentrations $(0.05 \%, 0.5 \%$ and $1 \%)$ for three periods of time $(2,4$ and 6 hours). The evaluations were performed according to pre-established criteria of tissue integrity and staining. The germination test was performed, using the $\mathrm{GA}_{4+7}+\mathrm{N}$-(fenilmetil)-aminopurina regulators at concentrations of 0 and $300 \mathrm{mg} . \mathrm{L}^{-1}$, because dormancy is observed in species of the family Annonaceae. Tetrazolium salt at 1\% yielded the highest percentage of viable seeds within the shortest time, while longer exposure times were necessary with concentrations of $0.05 \%$ and $0.5 \%$. It can be concluded that the concentration of $1 \%$ of tetrazolium salt for two hours of exposure is more appropriate for assessing the viability of atemoya seeds.
\end{abstract}

Index terms: Annonaceae, 2,3,5 triphenyltetrazolium chloride, germination test.

\section{Teste de tetrazólio para a avaliação da viabilidade de sementes de atemoia (Annona cherimola Mill. x A. squamosa L.)}

\begin{abstract}
RESUMO - O trabalho teve por objetivo adequar o teste de tetrazólio para a avaliação da viabilidade de sementes de atemoia (Annona cherimola Mill. x A. squamosa L.). O delineamento experimental utilizado foi inteiramente casualizado em esquema fatorial 3 x 3 (concentrações do sal de tetrazólio x períodos de exposição), totalizando 9 tratamentos com quatro repetições de 25 sementes. Após a imersão em água por 24 horas, as sementes foram seccionadas longitudinalmente e expostas a três concentrações do sal de tetrazólio $(0,05 \%, 0,5 \%$ e $1 \%)$ por três períodos $(2,4$, e 6 horas). As avaliações foram realizadas de acordo com critérios pré-estabelecidos de coloração e integridade dos tecidos. Foi também conduzido o teste de germinação, empregando-se as concentrações de 0 e 300 mg. $\mathrm{L}^{-1}$ dos reguladores $\mathrm{GA}_{4+7}+\mathrm{N}$-(fenilmetil)-aminopurina, devido à dormência existente em espécies da família Annonaceae. Com a concentração de 1\% do sal de tetrazólio foi possível vizualizar a maior porcentagem de sementes viáveis no menor tempo, ao passo que com as concentrações de $0,05 \%$ e $0,5 \%$ houve a necessidade de se utilizar os maiores tempos de exposição. Conclui-se que para sementes de atemoia, a concentração de $1 \%$ por duas horas de exposição ao sal de tetrazólio é a mais adequada para a avaliação da viabilidade.
\end{abstract}

Termos para indexação: Annonaceae, cloreto de 2,3,5 trifeniltetrazólio, teste de germinação.

\section{Introduction}

Atemoya (Annona cherimola Mill. x Annona squamosa L.) is a hybrid belonging to the family Annonaceae. It is being increasingly produced because of high domestic consumption

Submitted on 07/01/2014. Accepted for publication on 08/14/2014. ${ }^{2}$ Departamento de Botânica, UNESP, 18618970 - Botucatu, SP, Brasil. ${ }^{3}$ Instituto de Biociências, Departamento de Botânica, UNESP, Caixa Postal 510, 18618-000 - Botucatu, SP, Brasil. and increased exports. Grafting is recommended for the propagation of this species, but there are few alternatives for compatible rootstock species (Kavati, 2013). One solution is to use atemoya itself as a rootstock, whereby the seedlings are obtained from the seeds. This process has lower cost, poses no

${ }^{4}$ Departamento de Produção e Melhoramento Vegetal, UNESP, Caixa Postal 237, 18610-307 - Botucatu, SP, Brasil.

*Corresponding author< juliana@ibb.unesp.br> 
risk of incompatibility and ensures the advantages of grafting (Tokunaga, 2000; Baron et al., 2013).

Although the rootstock is formed from seeds, it should be noted that species belonging to the family Annonaceae present dormancy. Therefore, germination is slow and uneven (Ferreira et al., 2013). In this context, research has been conducted over time with the use of plant growth regulators in order to promote germination in species of the family Annonaceae used as crown or rootstock (Ferreira et al., 2014; Gimenez et al., 2014). For atemoya seeds, Braga et al. (2010) obtained the highest germination percentage (95.4\%) using a concentration of 329 mg.L $\mathrm{L}^{-1}$ of $\mathrm{GA}_{4+7}+\mathrm{N}$-(phenylmethyl)-aminopurine.

Assessment of seed viability using tests such as the germination test has some disadvantages: it takes longer to produce results, and it does not account for dormant seeds. Thus, it provides information about germination percentage rather than percentage of viable seeds. In contrast, the tetrazolium test is a quick alternative with accurate results, and it does not depend on seed dormancy (França-Neto et al., 1999).

The tetrazolium test is based on the activity of dehydrogenase enzymes, particularly malic acid dehydrogenase, which transfer $\mathrm{H}^{+}$ions released during respiration and interact with 2,3,5-triphenyltetrazolium chloride $\left(\mathrm{C}_{19} \mathrm{H}_{15} \mathrm{~N}_{4} \mathrm{Cl}\right)$. As a result, a red compound is formed (triphenylformazan). The carmine red color resulting from this reaction indicates respiratory activity in mitochondria; thus, the tissue is alive, or viable (Brasil, 2009).

However, the efficiency of the tetrazolium test depends on the development of a suitable methodology for each species, and it is necessary to define the concentration of the tetrazolium salt, the time and temperature of exposure of the seeds, in addition to the ideal cutting for exposure of the embryonic tissue (Bhering et al., 2005). The tetrazolium test is classified as a rapid, efficient test used routinely to evaluate seed viability of crop species (Brasil, 2009) and several others such as Clitorea ternatea (Deminicis et al., 2009), Acrocomia aculeata (Ribeiro et al., 2010), Leucena leucocephala x L. diversifolia (Costa and Santos, 2010).

The objective of this study was to adapt the tetrazolium test methodology for assessing the viability of atemoya seeds (Annona cherimolla Mill. x A. squamosa L.), using different exposure times and concentrations of the tetrazolium salt.

\section{Material and Methods}

Atemoya seeds (Annona cherimolla Mill. x A. squamosa L.) were manually extracted and left for surface drying on a benchtop for 24 hours. Later, these seeds were imbibed in water for 24 hours at $25{ }^{\circ} \mathrm{C} \pm 2{ }^{\circ} \mathrm{C}$ under constant aeration by means of aquarium pumps.

The experimental design was completely randomized in a $3 \times 3$ factorial arrangement (tetrazolium concentrations $\mathrm{x}$ exposure times), totaling nine treatments with four replicates of 25 seeds each. The seeds were cut longitudinally and immersed in tetrazolium solution (concentrations of $0.05 \%, 0.5 \%$ and $1 \%)$ in black germination boxes $(10 \times 10 \times 2 \mathrm{~cm})$ for 2,4 and 6 hours under a constant temperature of $30{ }^{\circ} \mathrm{C} \pm 2{ }^{\circ} \mathrm{C}$.

After the exposure period, the seeds were washed in running water and kept submerged in deionized water until the time of analysis. The assessment was performed with a magnifying glass by observing the resulting color and tissue integrity. The seeds were classified as viable or nonviable according to the following criteria: 1 - colored embryo and endosperm, and firm tissue (viable); 2 - colored embryo, uncolored endosperm and firm tissue (viable); 3 - embryo and endosperm with intense red color and flaccid tissue (nonviable); 4 - embryo with intense red color and damaged tissue (nonviable); 5 - uncolored embryo and endosperm (nonviable); 6 - uncolored embryo and endosperm, and damaged tissue (nonviable) (Figure 1).
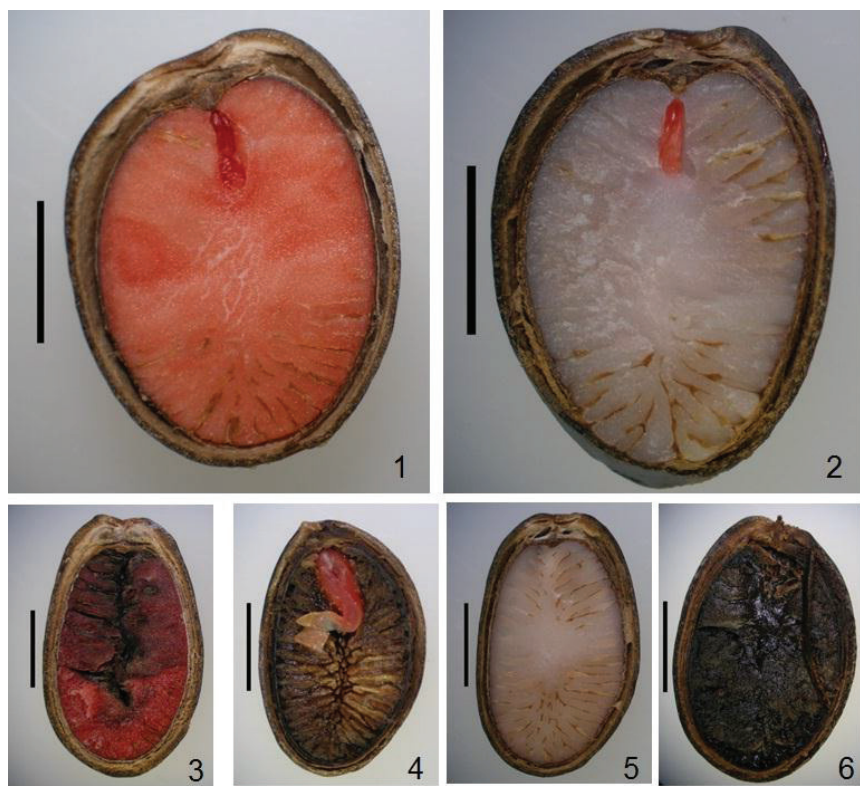

Figure 1. Criteria used in assessing the viability of atemoya seeds (Annona cherimola Mill. x A. squamosa L.): 1 - colored embryo and endosperm and firm tissue (viable); 2 - colored embryo, uncolored endosperm and firm tissue (viable); 3 - embryo and endosperm with intense red color and flaccid tissue (nonviable); 4 - embryo with intense red color and damaged tissue (nonviable); 5 - uncolored embryo and endosperm (nonviable); 6 - uncolored embryo and endosperm, and damaged tissue (nonviable). Scale corresponds to $5 \mathrm{~mm}$. 
In addition to the tetrazolium test, the seed germination test was performed with seeds from the same lot. They were subjected to two treatments: immersion in water and in solution of $300 \mathrm{mg} . \mathrm{L}^{-1}$ of $\mathrm{GA}_{4+7}+\mathrm{N}$-(phenylmethyl) aminopurine (Braga et al., 2010) with aeration and constant temperature $25{ }^{\circ} \mathrm{C} \pm 2{ }^{\circ} \mathrm{C}$ for 32 hours in the dark. After the immersion period, the seeds were stored in germitest paper rolls moistened with a volume of water equivalent to 2.5 times its dry weight, using four replicates of 25 seeds per plot. The rolls were kept in an incubator with alternating temperature and photoperiod $\left(20{ }^{\circ} \mathrm{C}\right.$ for 8 hours dark, $30{ }^{\circ} \mathrm{C}$ for 16 hours light). Assessments were performed at 15 and 30 days. Seeds were considered as germinated when they had at least $2.0 \mathrm{~mm}$ of primary root (Alvarenga et al., 2013). Data were subjected to analysis of variance (F-test) and means were compared by Tukey's test at 5\% significance (Mischan and Pinho, 1996).

\section{Results and Discussion}

The tetrazolium test was efficient at assessing the viability of atemoya seeds. The highest percentage of viable seeds was obtained with the highest concentration of the tetrazolium salt (1\%) and two hours of exposure (Table 1). However, there was a high percentage of viable seeds when the lowest concentrations of salt were used for longer exposure periods. Thus, the highest percentages of viable seeds exposed to the concentration of $0.05 \%$ was observed at four and six hours of exposure to the tetrazolium salt ( $61 \%$ and $66 \%$, respectively). When the concentration of $0.5 \%$ was used, the time required for a higher percentage of viable seeds $(76 \%)$ was increased to six hours.

Similarly to the results in this study, although with different concentrations, Fogaça et al. (2006) obtained satisfactory responses in seeds of Gleditschia amorphoides using higher concentrations $(0.10 \%)$ with shorter incubation time ( 1 hour) in tetrazolium salt or lower concentrations $(0.050 \%$ and $0.075 \%)$ for longer incubation times (3 and 6 hours). In contrast, Costa and Santos (2010) observed that lower concentrations $(0.15 \%)$ were the most effective in seeds of Leucaena leucocephala, while the use of the $1 \%$ concentration hindered the interpretation of the results due to the intense staining of tissues, unlike the findings for atemoya seeds in this study. However, in those studies, scarification and removal of the seedcoat was required for conducting the tetrazolium test, unlike seeds of $A$. muricata and $A$. cherimola (Lobo et al., 2007), in which the test is performed on seeds sectioned longitudinally, in the same way as done in the present study.

Several factors can influence the color and penetration of the tetrazolium salt, such as tissue morphology and consistency; thus, it is difficult to standardize and interpret the results (Socolowski et al., 2012). Another factor to consider is the chemical composition of seeds, since in oleaginous species there is lesser diffusion of the tetrazolium salt solution in the tissues, hampering visualization of the results (Wood et al., 2005). This was also observed in seeds of Acrocomia aculeata (Ribeiro et al., 2010). However, no difficulties were found in this study for the analysis of results, although atemoya seeds had predominantly lipid reserves, in the same manner as other species of the family Annonaceae, such as $A$. muricata (Kimbonguila et al., 2010), A. squamosa (Masruri et al., 2012) and Rollinia mucosa (Soares et al., 2014).

Because of factors relative to the standardization of the method, different results are obtained between genera of the same family and even between species of the same genus. In seeds of monkey pepper (Xylopia aromatica (Lam.) Mart.), viable seeds could be visualized with the use of $0.5 \%$ tetrazolium salt for 24 hours at $30{ }^{\circ} \mathrm{C}$ (Socolowski et al., 2012), while in seeds of $A$. cherimola and $A$. muricata, Lobo et al. (2007) recommended the $1 \%$ concentration of the tetrazolium salt at $30{ }^{\circ} \mathrm{C}$. However, these authors noticed a need for a period of 24-hour exposure to the salt, unlike the finding observed in this study with atemoya seeds, in which only two hours at $30{ }^{\circ} \mathrm{C}$ were sufficient to visualize viable seeds. It should be noted that high temperatures favor the staining of oilseeds (Wood et al., 2005), which justifies the satisfactory results with seeds of Annonaceae incubated at $30{ }^{\circ} \mathrm{C}$ in the tetrazolium salt solution.

Table 1. Viable seeds (\%) and nonviable seeds (\%) of atemoya (Annona cherimolla Mill. x A. squamosa L.) treated with concentrations of tetrazolium salt at different exposure times.

\begin{tabular}{cccc}
\hline \multirow{2}{*}{$\begin{array}{c}\text { Exposure time } \\
\text { (hours) }\end{array}$} & \multicolumn{3}{c}{ Tetrazolium concentrations } \\
\cline { 2 - 4 } 2 & $0.05 \%$ & $0.5 \%$ & $1 \%$ \\
\cline { 2 - 4 } 4 & $44 \mathrm{bC}^{*}$ & $61 \mathrm{abB}$ & $80 \mathrm{aA}$ \\
6 & $61 \mathrm{aA}$ & $56 \mathrm{bA}$ & $62 \mathrm{bA}$ \\
6 & $66 \mathrm{aA}$ & $76 \mathrm{aA}$ & $73 \mathrm{abA}$ \\
\hline C.V. $(\%)$ & & 14.37 \\
\hline & $56 \mathrm{aA}$ & $39 \mathrm{abB}$ & $20 \mathrm{bC}$ \\
4 & $39 \mathrm{bA}$ & $44 \mathrm{aA}$ & $38 \mathrm{aA}$ \\
6 & $34 \mathrm{bA}$ & $24 \mathrm{bA}$ & $27 \mathrm{abA}$ \\
\hline C.V. $(\%)$ & & 25.92 \\
\hline
\end{tabular}

* Means followed by the same letter, lowercase in the column and uppercase on the line, do not differ by Tukey's test at $5 \%$ significance. 
The reported physiological dormancy for atemoya seeds (Braga et al., 2010) is evident when examining the results of the germination test (Figure 2) together with those of the tetrazolium test. Even with the detection of $80 \%$ of viable seeds by the tetrazolium test, the highest germination percentage (44\%) was only achieved when plant growth regulators were used. In the first assessment, 15 days after the germination test was set up, seeds had not germinated in any of the treatments and, at 30 days, the seeds immersed in water showed 5\% germination while those immersed in $300 \mathrm{mg} . \mathrm{L}^{-1}$ of regulators $\mathrm{GA}_{4+7}+\mathrm{N}$-(phenylmethyl) aminopurine showed $44 \%$ of germinated seeds.

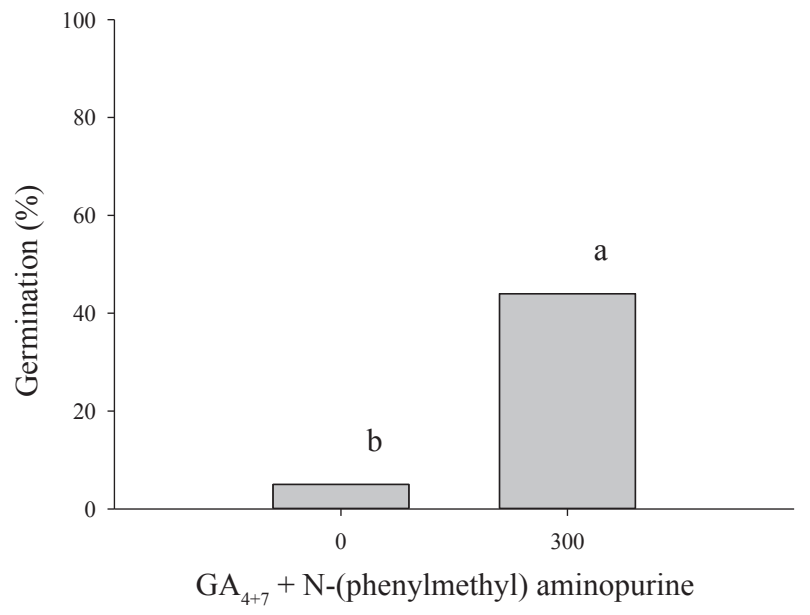

Figure 2. Germination of atemoya seeds (Annona cherimolla Mill. x A. squamosa L.) treated with concentrations of 0 and $300 \mathrm{mg} \cdot \mathrm{L}^{-1}$ of $\mathrm{GA}_{4+7}+\mathrm{N}$-(phenylmethyl) aminopurine $\left(\mathrm{GA}_{4+7}+\mathrm{CK}\right)$. Means followed by the same letter do not differ by Tukey's test at 5\% significance.

Thus, the germination test alone is not sufficient to determine the percentage of live seeds in the lot, which justifies the use of the tetrazolium test to assess seed viability, even in species with physiological dormancy, such as atemoya.

\section{Conclusions}

The concentration of $1 \%$ for two hours of exposure to the tetrazolium salt under a constant temperature of $30{ }^{\circ} \mathrm{C}$ is the most suitable condition for assessing the viability of atemoya seeds (Annona cherimola Mill. x A. squamosa L.).

\section{References}

ALVARENGA, R.O.; MARCOS-FILHO, J.; TIMÓTEO, T.S. Assessment of the physiological potential of super sweet corn seeds. Journal of Seed Science, v.35, n.3, p.340-346, 2013. http://www.scielo.br/scielo.php?pid=S2317$15372013000300010 \&$ script $=$ sci $\operatorname{arttext}$

BARON, D.; FERREIRA, G.; BOARO, C.S.F. Nutrição mineral em mudas de anonáceas. In: FERREIRA, G.; KAVATI, R.; BOARO, C.S.F.; FERRARI, T.B.; LEONEL, S. (Ed.) Anonáceas: propagação e produção de mudas. Botucatu: FEPAF. 2013. p.149-167.

BHERING, M.C.; DIAS, D.C.F.D.; BARROS, D.I. Adequação da metodologia do teste de tetrazólio para avaliação da qualidade fisiológica de sementes de melancia. Revista Brasileira de Sementes, v.27, n.1, p. 176-182, 2005. http://www.scielo.br/pdf/rbs/v27n1/25196.pdf

BRAGA, J.F.; FERREIRA, G.; PINHO, S.Z.; BRAGA, L.F.; SOUSA, M.P. Germination of atemoya (Annona cherimola Mill. x A. squamosa L.) cv. Gefner seeds subjected to treatments with plant growth regulators. International Journal of Science and Nature, v.1, n.2, p.120-126, 2010. http:// www.scienceandnature.org/IJSN_V1(2)_D2010/IJSN_V1(2)_6.pdf

BRASIL. Ministério da Agricultura, Pecuária e Abastecimento. Regras para análise de sementes. Ministério da Agricultura, Pecuária e Abastecimento. Secretaria de Defesa Agropecuária. Brasília: MAPA/ACS, 2009. 395p. http:// www.agricultura.gov.br/arq_editor/file/2946_regras_analise_sementes.pdf

COSTA, C.J.; SANTOS, C.P. Teste de tetrazólio em sementes de leucena. Revista Brasileira de Sementes, v.32, n.2, p.66-72, 2010. http://www.scielo. br/scielo.php?pid=S0101-31222010000200008\&script=sci_arttext

DEMINICIS, B.B.; VIEIRA, H.D.; SILVA, R.F. Teste de tetrazólio para avaliação da qualidade de sementes de Clitorea ternatea L.. Revista Brasileira de Sementes, v.31, n.2, p.54-62, 2009. http://www.scielo.br/pdf/ $\mathrm{rbs} / \mathrm{v} 31 \mathrm{n} 2 / \mathrm{v} 31 \mathrm{n} 2 \mathrm{a} 06 . \mathrm{pdf}$

FERREIRA, G.; GIMENEZ, J.I.; CORSATO, J.M.; OLIVEIRA, M.C Germinação de sementes de anonáceas. In: FERREIRA, G.; KAVATI, R.; BOARO, C.S.F.; FERRARI, T.B.; LEONEL, S. (Ed.) Anonáceas: propagação e produção de mudas. Botucatu: FEPAF. 2013. p.19-43.

FERREIRA, G.; GONZÁLEZ-ESQUINCA, A.R.; LA-CRUZ-CHACÓN, I. Water uptake by Annona diversifolia Moc. \& Sessé Ex Dunal Seeds (Annonaceae). Revista Brasileira de Fruticultura, v.36, p.288-295, 2014. http:// www.scielo.br/scielo.php?pid=S0100-29452014000500034\&script=sci_arttext

FOGAÇA, C.A.; MALAVASI, M.M.; ZUCARELI, C.; MALAVASI, U.C. Aplicação do teste de tetrazólio em sementes de Gleditschia amorphoides Taub. Caesalpinaceae. Revista Brasileira de Sementes, v.28, n.3, p.101-107, 2006. http://www.scielo.br/pdf/rbs/v28n3/15.pdf

FRANÇA-NETO, J.B.; KRZYZANOWSKI, F.C.; COSTA, N.P. Metodologia do teste de tetrazólio em sementes de soja. In: KRZYZANOWSKI, F.C.; VIEIRA, R.D.; FRANÇA-NETO, J.B. (Ed.). Vigor de sementes: conceitos e testes. Londrina: ABRATES. 1999. p. 8.5-1 - 8.5-28.

GIMENEZ, J.I.; FERREIRA, G.; CORSATO, J.M. Soluble sugars and germination of Annona emarginata (Schltdl.) H. Rainer seeds submitted to immersion in $\mathrm{GA}_{3}$ up to different water contents. Revista Brasileira de Fruticultura, v.36, p.281-287, 2014. http://www.scielo.br/scielo. php?pid=S0100-29452014000500033\&script=sci_arttext

KAVATI, R. Porta-enxertos em anonáceas. In: FERREIRA, G.; KAVATI, R.; BOARO, C.S.F.; FERRARI, T.B.; LEONEL, S. (Ed.) Anonáceas: propagação e produção de mudas. Botucatu: FEPAF. 2013. p.111-123. 
KIMBONGUILA, A.; NZIKOU, J.M.; MATOS, L.; LOUMOUAMOU, B.; NDANGUI, C.B. Proximate composition and physicochemical properties on the seeds and oil of Annona muricata grown in Congo - Brazzaville. Research Journal of Environmental and Earth Sciences, v.2, n.1, p.13-18, 2010. http://maxwellsci.com/print/rjees/v2-13-18.pdf

LOBO, M.; DELGADO, Ó.; CARTAGENA, J.R.; FERNÁNDEZ, E.; MEDINA, C.I. Categorización de la germinación y la latencia em semillas de chirimoya (Annona cherimola L.) y guanábana (Annona muricata L.) como apoyo a programas de conservación de germoplasma. Agronomía Colombiana, v.25, n.2, p.231-244, 2007. http://www.scielo.org.co/scielo. php?pid=S0120-99652007000200005\&script=sci_arttext

MASRURI, L.; MUKESH, S.; WARSITO, L.; PRASETYO, A. Renewable oil extracted from Indonesian Srikaya's (Annona squamosa sp.) seed: another potent source for biodiesel. Journal Pure Applied Chemistry Research, v.1, n.1, p.51-57, 2012. http://jpacr.ub.ac.id/index.php/jpacr/article/viewFile/106/104

MISCHAN, M.M.; PINHO, S.Z. Experimentação agronômica - Dados não balanceados. Botucatu, Fundibio. 1996. 457p.

RIBEIRO, L.M.; GARCIA, Q.S.; OLIVEIRA, D.M.T.; NEVES, S.C. Critérios para o teste de tetrazólio na estimativa do potencial germinativo em macaúba. Pesquisa Agropecuária Brasileira, v.45, n.4, p.361-368, 2010. http://www. scielo.br/scielo.php?pid=S0100-204X2010000400003\&script=sci arttext
SOARES, J.D.R.; DIAS, G.M.G.; RODRIGUES, F.A.; PASQUAL, M.; CHAGAS, E.A. Caracterização anatômica e citométrica em biribazeiro (Rollinia mucosa [Jacq.]). Revista Brasileira de Fruticultura, v.36, p.272-280, 2014. http://www.scielo.br/scielo.php?pid=S0100$29452014000500032 \&$ script $=$ sci_arttext

SOCOLOWSKI, F.; CICERO, S.M.; VIEIRA, D.C.M. Viability of recently harvested and stored Xylopia aromatica (Lam.) Mart. (Annonaceae) seeds. Revista Brasileira de Sementes, v.34, n.3, p.408-415, 2012. http://www. scielo.br/scielo.php?script=sci_arttext\&pid=S0101-31222012000300007

TOKUnAGA, T. A cultura da Atemóia. Campinas: CATI, 2000. 80p. (Boletim técnico, 233).

WOOD, C.B.; MILES, S.; RIX, C.; TERRY, J.; DAWS, M.I. The effect of seed oil content on viability assessment using tetrazolium: a case study using 171 species. Plant Genetic Resources Newsletter, v.143, p.17-23, 2005. http://www.bioversityinternational.org/fileadmin/PGR/article-issue_143art_3-lang_en.html 